\title{
Comparison between High Performance Thin Layer Chromatography and High Performance Liquid Chromatography Methods for Determination of Rubraxanthone in the Stem Bark Extract of Garcinia cowa Roxb
}

\author{
Meri Susanti ${ }^{1}$, Sanusi Ibrahim ${ }^{2}$, Yahdiana Harahap ${ }^{3}$, Dachriyanus ${ }^{1, *}$
}

\section{Meri Susanti ${ }^{1}$, Sanusi Ibrahim², Yahdiana Harahap $^{3}$, Dachriyanus ${ }^{1, *}$ \\ 'Faculty of Pharmacy, Andalas University, West Sumatra, 25163, INDONESIA. ${ }^{2}$ Department of Chemistry, Faculty of Mathematics and Natural Sciences, An- dalas University, West Sumatra, 25163, INDONESIA. \\ ${ }^{3}$ Faculty of Pharmacy, Universitas Indonesia, 16424, INDONESIA. \\ Correspondence}

Prof. Dachriyanus

Faculty of Pharmacy, Andalas University, Kampus Limau Manis, Padang, West Sumatra, 25163, INDONESIA.

Phone no : +6275171682

E-mail: dachriyanus@phar.unand.ac.id

History

- Submission Date: 05-05-2018;

- Review completed: 22-06-2018

- Accepted Date: 18-09-2018

DOI : 10.5530/pj.2018.6s.8

Article Available online

http://www.phcogj.com/v10/i6s

\section{Copyright}

(C) 2018 Phcog.Net. This is an openaccess article distributed under the terms of the Creative Commons Attribution 4.0 International license.

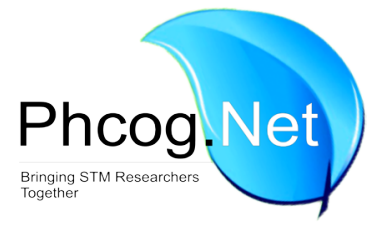

\begin{abstract}
Objectives: To develop simple, rapid, accurate methods for determination of rubraxanthone in the stem bark extract of Garcinia cowa using High Performance Thin Layer Chromatography (HPTLC) and High Performance Liquid Chromatography (HPLC). Methods: The HPTLC method was performed on aluminum plate precoated with silica gel $60 \mathrm{~F}_{254}$ using Chloroform: Ethyl acetate: Methanol: Formic acid (88:2:2:8) as a developing system. Quantification was achieved using densitometric measurements at $243 \mathrm{~nm}$. The HPLC method involved a $5 \mu \mathrm{m} \mathrm{C18}$ column and an isocratic solvent using $0.4 \%$ formic acid: methanol (12:88) with a flow rate $1 \mathrm{~mL}$ minute $^{-1}$. Quantitation was also achieved with ultraviolet detection at $243 \mathrm{~nm}$ based on peak area. All necessary validation tests for both methods were done for their comparison. The results obtained by these two different quantification methods were compared by Tukey's-test. Results: Both assays provided good linearity, accuracy, precision, specificity and limits of detection and quantitation for determination of rubraxanthone in The Stem Bark extract of $G$. cowa. Conclusion: Both methods revealed reasonable validation parameters concerning linearity, accuracy, precision, specificity and limits of detection and quantitation. A statistical comparison of the quantitative analysis of rubraxanthone in extract did not show any statistically significant difference between two analysis methods. As both methods were found to be equal, they therefore can be used for the analysis of rubraxanthone in the Stem Bark extract of $G$. cowa.
\end{abstract}

Key words: High Performance Liquid Chromatography, High Performance Thin Layer Chromatography, Rubraxanthone, Garcinia cowa Roxb.

\section{INTRODUCTION}

Garcinia cowa Roxb, Guttiferae, commonly known as Cha-muang in Thai, is widely distributed throughout Malaysia, Thailand, Indonesia and Myanmar. G. cowa is a medicinal has been widely used and traded by the Asian community as a traditional medicine to treat various diseases such as diarrhea, skin infections, wounds and as an anti-septic. Various parts of this plant have been used in traditional folk medicine. The bark, latex and root have been used as an antipyretic agent, while fruit and leaves have been used as an expectorant, for indigestion and improvement of blood circulation.

Previous phytochemical studies on G. cowa have reported this plant as one of the richest sources of xanthones. Thirty six xanthones have been isolated and twenty of them were isolated from stem bark. ${ }^{1}$ The major active compound from this stem bark was rubraxanthone. ${ }^{2}$ In recent years, there has been strong interest in the stem bark G. cowa (rubraxanthones) due to its remarkable pharmacological effects such as antiimflamatory agent, ${ }^{3}$ antimicrobial and antioxidant. ${ }^{4-5}$ It also has anticancer activity against breast cancer (MCF-7), human prostate cancer (DU-145) and lung cancer $(\mathrm{H}-460)^{6}$ as well as can reduce total cholesterol and triglyceride levels in the blood of male rats. ${ }^{7}$ Because of the growing interest in G. cowa, reliable procedures are needed for quantitative determination of its bioactive principles and quality control assurance.

Few analytical methods have been reported for the standardization and quality control of $G$. cowa extract. The HPLC method have so far been published for estimation of rubraxanthone in methanolic stem bark extract of Garcinia mangostana and latex of G. cowa. ${ }^{8-9}$ HPTLC system was also used to quantify rubraxanthone in ethyl acetate stem bark extract of G. cowa. ${ }^{10}$

Cite this article: Susanti M, Ibrahim S, Harahap Y, Dachriyanus. Comparison between High Performance Thin Layer Chromatography and High Performance Liquid Chromatography Methods for Determination of Rubraxanthone in the Stem Bark Extract of Garcinia cowa Roxb. Pharmacog J. 2018;10(6)Suppl:s42-s47. 
The purpose of the present work was to develop the most simple, rapid and accurate method to determine concentration of rubraxanthone in dichloromethane stem bark extract of G. cowa by using HPTLC densitometry and HPLC methods and to compare results obtained by HPTLC and HPLC methods.

\section{MATERIALS AND METHODS}

\section{Plant Materials}

Stem bark of G. cowa was collected from Limau Manih, West Sumatra. The plants sample were identified by taxonomist from Herbarium ANDA Andalas University. The barks were cut into small pieces and dried in a hot oven at $50^{\circ} \mathrm{C}$ for $72 \mathrm{~h}$. The dried samples were ground into powder and passed through a sieve (20 meshes).

\section{Preparation of Extract}

Fine powder of G. cowa stem bark was defatted by n-hexane and then extracted with dichloromethane using Soxhlet extraction method, until the solvent become less color. This extract was then concentrated to dryness by removing the solvent in the rotary evaporator under reduced pressure.

\section{Determination of the Yield Plant Extract}

The percentage yield of extract obtained from stem bark of G. cowa was calculated from the following equation:

$$
\% \text { yield }=\frac{(\mathrm{w} 1 \times 100)}{\mathrm{w} 2} \%
$$

Where W1 was the weight of the extract after the solvent evaporation and W2 was the weight of powdered stem bark of G. cowa taken.

\section{Chemicals}

All reagents and solvents were analytical and HPLC grades (merck), except formic acid. Rubraxanthone (standard) markers were obtained from the Centra Laboratory, Faculty of Pharmacy of Andalas University (Padang, Indonesia), which was previously isolated from Garcinia plant. ${ }^{9}$

\section{Chromatographic Conditions for High Performance Thin Layer Chromatography}

HPTLC analysis was performed using an HPTLC system (CAMAG, Switzer Land). Precoated silica gel 60 F254 TLC plates $(20 \mathrm{~cm} .20 \mathrm{~cm})$, layer thickness of $0.2 \mathrm{~mm}$ (E. Merck KGaA, Darmstadt, Germany), were used as stationary phase. A volume of $5 \mu \mathrm{L}$ standard and sample solutions were applied to the chromatographic plates using CAMAG Nanomat 4 semiautomatic TLC sampler. The Linear ascending development was carried out in the solvent system, Chloroform: Ethyl acetate: Methanol: formic acid $(88: 2: 2: 8 \mathrm{v} / \mathrm{v} / \mathrm{v} / \mathrm{v})$ in saturated mode of twin through chamber at room temperature. Then, the plate was dried at room temperature before densitometry scanning. The HPTLC plate was scanned at a wavelength of $243 \mathrm{~nm}$. The plate was densitometrically scanned with CAMAG TLC scanner 4. Densitogram was displayed by CAMAG win CATS computer program. Evaluation was done via peak area with Linear regression.

\section{Chromatographic Conditions for High Performance Liquid Chromatography}

HPLC method was performed on a Shimadzu (Kyoto, Japan) Liquid chromatography system, equipped with a model LC-20 AD pump, UV-Vis SPD M-20A Diode detector. Separation was performed in a $5 \mu \mathrm{m}$ C18 column Shimadzu Shimp-pack VP-ODS (4.6 x $250 \mathrm{~mm}$ ). The mobile phase was an isocratic solvent using $0.4 \% \mathrm{v} / \mathrm{v}$ formic acid methanol with a flow rate $1 \mathrm{~mL}$ minute ${ }^{-1}$. The mobile phase was prepared daily, filtered through a $0.22 \mu \mathrm{m}$ and degassed before use. Before the first injection, the column was saturated for $30 \mathrm{~min}$ with the initial mobile phase. The column temperature was maintained at $25^{\circ} \mathrm{C}$. Total running time was 14 minutes and the sample injection volume was $10 \mu \mathrm{L}$ while the wavelength of the UV-VIS detector was set at $243 \mathrm{~nm}$. The compound was quantified using CLASS VP software.

\section{Preparation of Standard Stock Solution of Rubraxanthone}

The stock solution of rubraxanthone reference standard was prepared by accurately weighing $10 \mathrm{mg}$ of standards quantitatively transferred into a volumetric flask and made up to volume with methanol to achieve concentration of $100 \mu \mathrm{g} / \mathrm{mL}$.

\section{Preparation of Sample for HPTLC Analysis}

The dichloro methane extract of stem bark G. cowa (11.2 mg) was accurately weighed and transferred to a $10 \mathrm{~mL}$ volumetric flask. Methanol was added to volume (final concentration $1120 \mu \mathrm{g} / \mathrm{mL}$ ). Aliquot of the solution $(1 \mathrm{~mL})$ was diluted with methanol in a $10 \mathrm{~mL}$ volumetric flask to make a concentration of $112 \mu \mathrm{g} / \mathrm{mL}$

\section{Preparation of Sample for HPLC Analysis}

The dichloromethane extract of the stem bark of $G$. cowa was prepared by weighing accurately $10,4 \mathrm{mg}$ of extract, dissolved in $50 \mathrm{~mL}$ methanol to achieve concentration of $208 \mu \mathrm{g} / \mathrm{mL}$. Further final concentration was made up to $50 \mu \mathrm{g} / \mathrm{mL}$ by dissolving $1 \mathrm{~mL}$ of stock solution in to $20 \mathrm{~mL}$ of mobile phase before inject.

\section{Validation of Method}

Vaidation of the analytical method was done according to the International Conference on Harmonization guideline (ICH, 1995). ${ }^{11}$ The technique was validated for Linearity, precision, accuracy, specificity and Limit of detection (LOD) and Limit of quantitation (LOQ).

\section{Statistical Analysis}

Values are expressed as a mean \pm SD. The statistical significance was calculated by one-way analysis of variance (ANOVA), followed by Tukey's test $(\mathrm{P}<0.05)$.

\section{RESULTS AND DISCUSSION}

\section{Estimation of Yield of Extract}

The percent yield of dichloromethane extract of G. cowa. Roxb stem bark was found to be $1.95 \% \mathrm{w} / \mathrm{w}$.

\section{HPTLC method optimization}

Experimental conditions such as mobile phase and wavelength of scanning were optimized to provide accurate, precise, selective and reproducible results for the determination of rubraxanthone. Different trials for optimization of the developing systems resulted in the selection of Chloroform: Ethyl acetate: Methanol: formic acid (88:2:2:8) as the best for the separation of rubraxanthone in extract. The wavelength achieving maximum sensitivity was $243 \mathrm{~nm}$. The specificity of the HPTLC method is illustrated in Figure 2, which shows complete separation of rubraxanthone and other peaks. It was found that the resolution was very good (resolution value $>1.5$ ). The $R_{f}$ values of rubraxanthone was found to be $0.42 \pm 0.05$ using the specified developing system. The relationship between the concentration of each compound and its corresponding peak area of the band was investigated. The Linear relationship was 
tested and found to be acceptable for rubraxanthone. The characteristic parameters of the Linear regression equation of rubraxanthone is shown in Table 1 .

\section{HPLC method optimization}

The developed HPLC method was applied for determination of rubraxanthone in the Stem Bark extract of G. cowa. To optimize the HPLC assay parameters, the mobile phase composition was studied. A satisfactory separation was obtained with a mobile phase consisting of $0.4 \%$ formic acid - methanol $(12: 88, \mathrm{v} / \mathrm{v})$ with a flow rate $1 \mathrm{~mL}$ minute $^{-1}$. Increasing methanol concentration to more than $90 \%$ led earlier elution of the rubraxanthone peak but with excessive tailing. At lower methanol concentration $(<85 \%)$, separation occurred too late. Quantitation was achieved with ultraviolet (UV) detection at $243 \mathrm{~nm}$ based on peak area. The specificity of the HPLC method is illustrated in Figure 3, which shows complete separation of the studied compounds. It was found that the resolution was very good (resolution value $>1.5$ ). The average retention time \pm standard deviation for rubraxanthone was found to be 9.889 $\pm 0.003 \mathrm{~min}$, for 10 replicates. The characteristic parameters of the Linear regression equation of the compound are shown in Table 1.

\section{Validation of the methods \\ Linearity}

The Linearity of the HPTLC and HPLC methods for the determination of rubraxanthone was evaluated by analyzing a series of different concentrations of rubraxanthone solution. In this study, seven concentrations were chosen in which reasonable linearity was achieved in the range of 1.02-5.01 $\mu \mathrm{g} / \mathrm{b}$ and for rubraxanthone using the HPTLC method and $1,01-10,10 \mu \mathrm{g} / \mathrm{mL}$ for rubraxanthone using the HPLC method. Each concentration was repeated three times to provide information on the variation in peak area values between samples of the same concentration. The Linearity of each calibration graphs validated by the high value of the correlation coefficient (Table 1).

\section{Precision}

For intra-day precision, three concentrations for rubraxanthone were analyzed seven times on the same day, whereas the same concentrations were analyzed on three different days for inter-day precision. Intra-day precision was expressed through relative standard deviation (RSD) of seven repeated assays of samples at three concentration levels. Inter-day precision was determined by analyzing the same set of samples on three

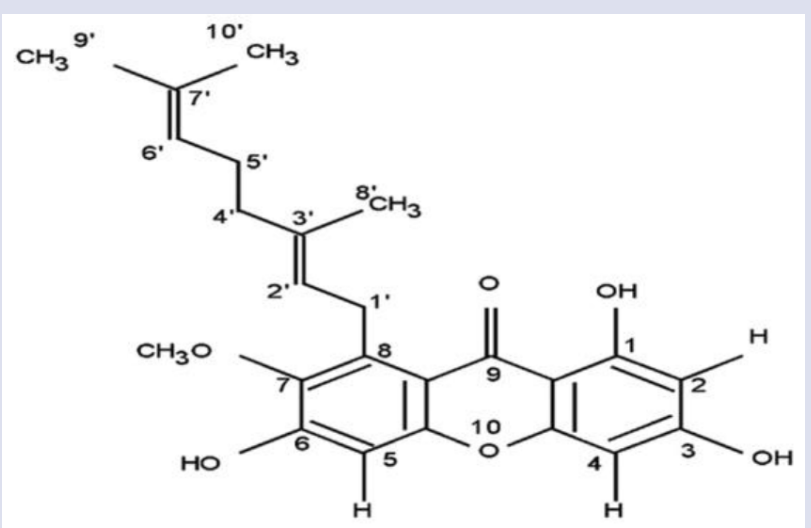

Figure 1: Structure of Rubraxanthone. ${ }^{2}$ different days. RSD in the precision study for the rubraxanthone assay was less than $2.0 \%$, which confirmed that the method was highly precise. Results of the precision study for rubraxanthone by the proposed HPTLC and HPLC methods are given in Table 2.

\section{Range}

The calibration range was established through consideration of the practical range necessary to give accurate, precise and linear results, according to concentration rubraxanthone present in the stem bark G. cowa extract. The calibration range of the proposed methods is given in Table 1.

\section{Detection and quantitation Limits}

According to the International Conference on Harmonization (ICH) recommendations ${ }^{11}$ the approach based on the Standard Deviation (SD)
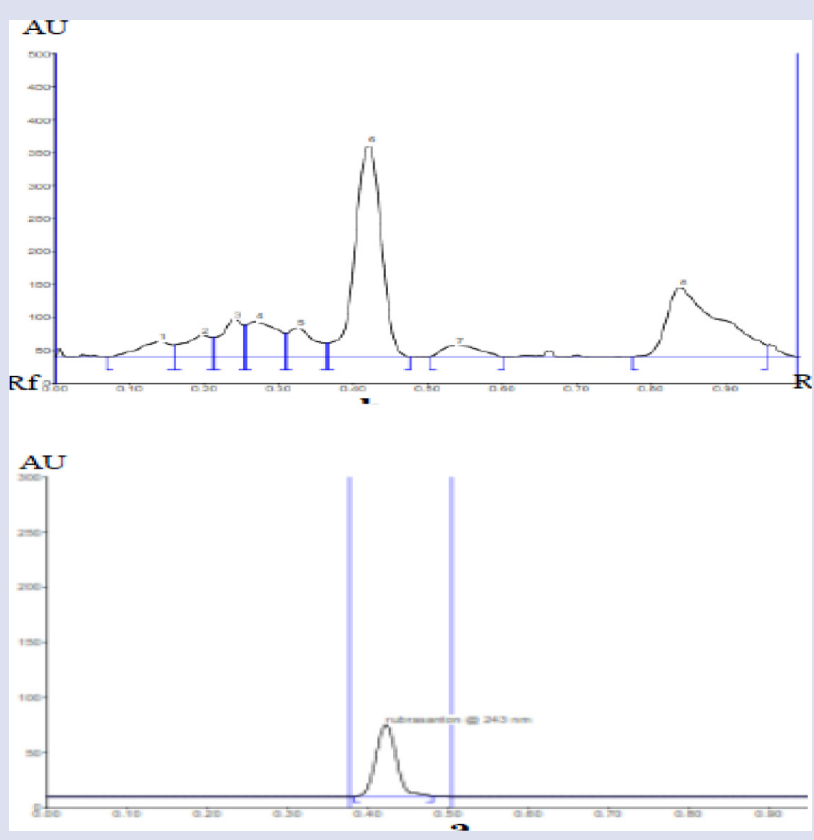

Figure 2: HPTLC chromatogram sample G. cowa R. extracts and standard rubraxanthone.
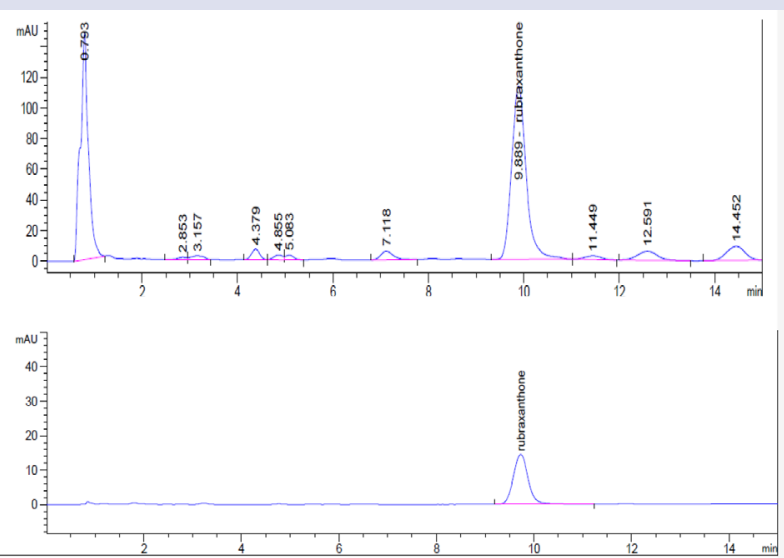

Figure 3: HPLC chromatograms of sample G. cowa R. extracts and standard rubraxanthone at $243 \mathrm{~nm}$. 
Table 1: Characteristic Parameters for the Regression Equations of the HPTLC and HPLC Methods for the Determination of Rubraxanthone in stem bark extract of G. cowa.

\begin{tabular}{|c|c|c|}
\hline Parameters & HPTLC method & HPLC method \\
\hline Calibration range ( $\mu \mathrm{g} / \mathrm{mL}$ for HPLC or $\mu \mathrm{g} / \mathrm{band}$ for HPTLC) & $1.02-5.01$ & $1.01-10.1$ \\
\hline \multicolumn{3}{|l|}{ Regression equation $(\mathrm{Y})^{*}$} \\
\hline Slope (b) & 59.753 & 346326.176 \\
\hline Standard deviation of the slope $\left(\mathrm{S}_{\mathrm{b}}\right)$ & 2.197 & 181.934 \\
\hline Relative standard deviation of the slope $\left(\mathrm{S}_{\mathrm{b}}\right)$ & 0.037 & 0.005 \\
\hline \multirow[t]{2}{*}{ Confidence Limit of the slope ${ }^{* *}$} & 59.687 & 34625.930 \\
\hline & 59.819 & 34626.070 \\
\hline Intercept (a) & -3.961 & 23387 \\
\hline Standard deviation of the intercept $\left(\mathrm{S}_{\mathrm{a}}\right)$ & 4.750 & 4713.066 \\
\hline \multirow[t]{2}{*}{ Confidence Limit of the intercept ${ }^{* *}$} & -4.027 & 23386.930 \\
\hline & -3.895 & 23387.070 \\
\hline Correlation coefficient (r) & 0.999 & 0.999 \\
\hline Detection Limit ( $\mu \mathrm{g} / \mathrm{mL}$ for HPLC or $\mu \mathrm{g} / \mathrm{band}$ for HPTLC) & 0.277 & 0.239 \\
\hline Quantitation Limit ( $\mu \mathrm{g} / \mathrm{mL}$ for HPLC or $\mu \mathrm{g} / \mathrm{band}$ for HPTLC) & 0.924 & 0.795 \\
\hline
\end{tabular}

${ }^{*} \mathrm{Y}=\mathrm{a}+\mathrm{bc}$, where $\mathrm{c}$ is the concentration of the substance in $\mu \mathrm{g} / \mathrm{mL}$ for HPLC or $\mu \mathrm{g} / \mathrm{b}$ and for HPTLC and $\mathrm{Y}$ is the peak area

**95\% confidence Limit, $\mathrm{n}=7$.

Table 2: Precision Data of the Proposed HPTLC and RP-HPLC Methods.

\begin{tabular}{|c|c|c|c|c|c|c|c|c|c|}
\hline \multicolumn{2}{|c|}{ Actual Concentration } & \multicolumn{8}{|c|}{ Measured Concentration } \\
\hline & & \multicolumn{4}{|c|}{ Intra-Day } & \multicolumn{4}{|c|}{ Inter-Day } \\
\hline HPTLC & HPLC & HPTLC & $\%$ RSD & HPLC & $\%$ RSD & HPTLC & $\%$ RSD & HPLC & $\%$ RSD \\
\hline 1.02 & 1.01 & $0.981 \pm 0.03$ & 0.634 & $1.068 \pm 0.01$ & 0.820 & $0.988 \pm 0.08$ & 0.642 & $1.085 \pm 0.02$ & 1.573 \\
\hline 3.02 & 5.05 & $2.958 \pm 0.06$ & 0.708 & $5.043 \pm 0.02$ & 0.046 & $2.607 \pm 0.339$ & 0.411 & $5.032 \pm 0.04$ & 0.804 \\
\hline 5.01 & 10.10 & $4.943 \pm 0.021$ & 0.842 & $10.176 \pm 0.09$ & 0.889 & $4.258 \pm 1.101$ & 0.595 & $10.32 \pm 0.135$ & 1.303 \\
\hline
\end{tabular}

Table 3: Rubraxanthone content in dichloromethane extract of $G$. cowa Stem bark determined by HPTLC and HPLC methods.

\begin{tabular}{ccc}
\hline \multicolumn{3}{c}{ Content of rubraxanthone $(\% \mathrm{w} / \mathrm{w})$} \\
\hline Samples & \multicolumn{2}{c}{ Mean \pm SD } \\
\hline \multicolumn{3}{c}{ HPTLC } \\
1. & $40.066 \pm 0.057^{*}$ & $40.092 \pm 0.044^{*}$ \\
2. & $40.090 \pm 0.055^{*}$ & $40.121 \pm 0.059^{*}$ \\
3. & $40.052 \pm 0.034^{*}$ & $40.061 \pm 0.038^{*}$ \\
4. & $40.124 \pm 0.019^{*}$ & $40.133 \pm 0.039^{*}$ \\
5. & $40.081 \pm 0.036^{*}$ & $40.092 \pm 0.055^{*}$ \\
\hline
\end{tabular}

${ }^{*}$ No Significant difference $(\mathrm{P}<0.05)$ when HPTLC and HPLC methods were compared

of the response and the slope was used for determining the detection and quantitation limits. The theoretical values were assessed practically and given in Table 1.

\section{Accuracy}

The proposed method was used for estimation of rubraxanthone from extract after spiking with $80 \%, 100 \%$ and $120 \%$ of additional standard of rubraxanthone to pre-analyzed sample. The recovery percent of rubraxanthone was found to be 106.99, 98.65 and 91.30 on HPTLC and 105.73, 99.87 and 100.75 on HPLC for $80 \%, 100 \%$ and $120 \%$, respectively, in extract.
Table 4: Other compound peaks identified in HPTLC spectrum of dichloromethane extract of G.cowa Stem Bark.

\begin{tabular}{ccc}
\hline Peak & Maximum Rf & Assigned Substance \\
\hline 1. & 0.14 & unknown \\
2. & 0.20 & unknown \\
3. & 0.24 & unknown \\
4. & 0.27 & unknown \\
5. & 0.32 & unknown \\
6. & 0.42 & rubraxanthone ${ }^{2}$ \\
7. & 0.54 & unknown \\
8 & 0.84 & unknown \\
\hline
\end{tabular}

\section{Specificity}

The specificity of the HPTLC method was ascertained by analyzing standard rubraxanthone and sample. The spots for rubraxanthone in Stem bark extract G. cowa were confirmed by comparing the Rf and UV spectra of the spot with that of standard. The peak purity of rubraxanthone was assessed by comparing their respective spectra at peak start, peak apex and peak end positions of the spot, that is, $r(S, M)=0.9993$ and $r(M, E)=0.9992$. Good correlation $(r=0.9992)$ was also obtained between standard and stem bark $G$. cowa extract spectra of rubraxanthone. The specificity of HPLC method was then performed by comparing the retention times of rubraxanthone in the chromatogram of the stem 
bark G. cowa extract extract with those in the chromatogram of the standard rubraxanthone. The representative HPLC chromatograms obtained from standard rubraxanthone and stem bark G. cowa extract are shown in Figure 3. It shows that no other co-eluting peak was found that would interfere with the main peaks, of rubraxanthone suggesting satisfactory specificity of the method with the retention time of $9.889 \pm$ $0.003 \mathrm{~min}$. The retention time is consistent with RSD lower than $0.2 \%$ $(n=10$, data not shown).

\section{Determination of Rubraxanthone in the Stem Bark Extract of G. cowa}

The proposed methods were applied for quantitative rubraxanthone in the Stem Bark Extract of G. cowa. The amount of rubraxanthone in stem bark G. cowa extract is determined by comparing to a rubraxanthone standard curve chromatographed under the same condition. The amount of rubraxanthone are shown in Table 3. The result of the Tukey'stest $(P<0.05)$ indicated that there was no significant difference between the mean values of rubraxanthone content. Therefore, both HPTLC and HPLC methods were found to be equal and can be used for the determination of rubraxanthone content in dicholoromethane extract of G. cowa stem bark.

\section{CONCLUSION}

According to statistical interpretation of results obtained from validation, the developed HPTLC and HPLC techniques are precise, sensitive, accurate and specific for the determination of rubraxanthone. Therefore, the proposed method can be used for qualitative as well as quantitative analyses of rubraxanthone in extracts which may be useful for standardization purposes. A statistical comparison of the quantitative rubraxanthone determination from dichloromethane extract of G. cowa stem bark did not show any statistical significance between HPLC and HPTLC.

\section{ACKNOWLEDGEMENT}

This research was funded by Andalas University through Hibah Guru Besar No. 09/UN.16.17/PP.HGB/LPPM/2018.

\section{CONFLICT OF INTEREST}

The authors declare that there is no conflict of interest.

\section{ABBREVIATIONS}

ICH: International Conference on Harmonization; LOD: limit of detection; LOQ: limit of quantitation

\section{REFERENCES}

1. Ritthiwigrom T, Laphookhieo S, Pyne SG. Chemical constituents and biological activities of Garcinia cowa Roxb. Maejo International Journal of Science and Technology. 2013;7(2):212-31.

2. Wahyuni FS, Byrne LT, Dachriyanus, Dianita $\mathrm{R}$, Jubahar J Lajis $\mathrm{NH}$, et al. A new ring-reduced tetraprenyltoloquinone and a prenylated xanthone frim Garcinia cowa. Auat J Chem. 2004;57(3):223-6.

3. Wahyuni FS, Ali DA, Lajis NH, Dachriyanus. Anti-inflammatory activity of isolated compounds from the stem bark of Garcinia cowa Roxb. Pharmacognosy Journal. 2017;9(1):55-7.

4. Lee $H$, Chan H. 1,3,6-trihydroxy-7-methoxy-8-(3,7-dimethyL-2,6-octadienyl) xanthone from Garcinia cowa. Phytochemistry. 1997;16(12):20038-40.

5. Dachriyanus, Dianita R, Jubahar J. Isolation of antioxidant compounds from the stem bark Garcinia cowa. Journal Mathematics and Natural Sciences. 2003; 12:67-72.

6. Wahyuni FS, Shaari K, StansLas J, Lajis NH, Dachriyanus. Cytotoxic xanthones from the stem bark of Garcinia cowa Roxb. Journal of Chemical and Pharmaceutical Research. 2015;7(1):227-36

7. Dachriyanus, Sartika L, Kesuma M, Mukhtar MH. The effect of rubraxanthone on total cholesterol, trigliseride, HDL and LDL in the blood white male mice. Journal of Science and Pharmaceutical Technology. 2006;11:12-5.

8. Dachriyanus, Nova SA, Meri S. Determination of Rubraxanthone in the Latex of Asam Kandis (Garcinia cowa Roxb) by Reverse Phase High Performance Liquid Chromatography. Pharmacognosy Journal. 2017;9(2):175-9.

9. Susanti M, Lena DI, Dachriyanus. Development and validation of a HPLC method for determination and quantification of rubraxanthone in stem bark extract of mangosteen. Indonesian Journal of Pharmacy. 2014;25(4):237-44.

10. Dachriyanus $H$, Aulia H, Susanti M. High Performance Thin Layer Chromatography: Densitometry Method for Determination of Rubraxanthone in the Stem Bark Extract of Garcinia cowa Roxb. Pharmacognosy Research. 2017;9(3):230-3.

11. International Conference on Harmonization. Guidance for Industry, Q2B: Validation of Analytical Procedures: Methodology. USA: International Conference on Harmonisation. 1995
GRAPHICAL ABSTRACT

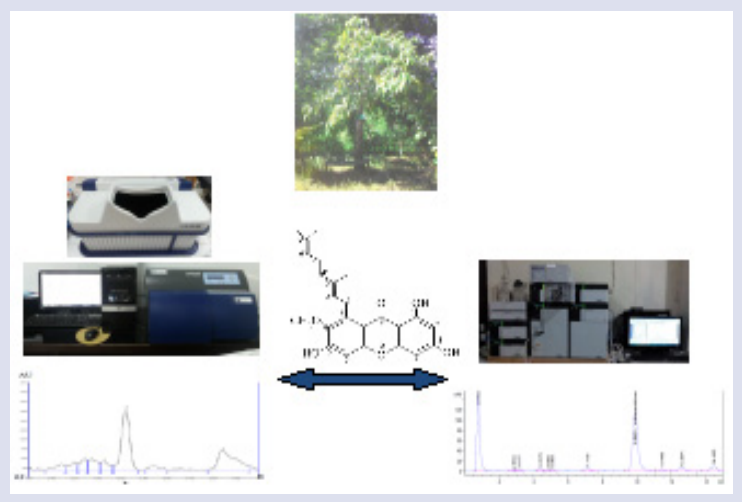

\section{SUMMARY}

- An HPTLC method was developed in comparison to HPLC method for quantitative analysis of rubraxnthone in The Stem bark extract of Garcinia cowa Roxb

- As both methods were found to be equal, they therefore can be used for the analysis of rubraxanthone in The Stem Bark extract of G. cowa

\section{ABOUT AUTHORS}

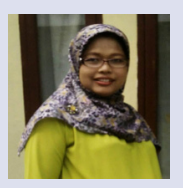

Meri Susanti is PhD student from Andalas University. She is positioned as young lecturer at Faculty of Pharmacy, Andalas University. Her research is in standardization of Sumatran medicinal plants especially Genus Garcinia

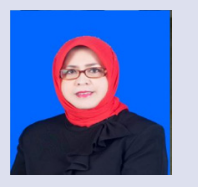

Yahdiana Harahap got her undergraduate degree from Indonesian University in 1987 and finished her PhD from Bandung Institute of Technology in 2003. She is positioned as Professor at Pharmacy at Faculty of Pharmacy Indonesian Univesity. Her research is in Pharmaceutical Chemistry Analysis, especially Bioanalysis and DNAAdduct Analysis 


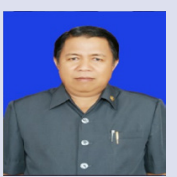

Sanusi Ibrahim got his undergraduate degrees from Andalas University and finished his PhD from Ecole Nationale Superieurde Chimie de Montpellier, Prancis. He is positioned as Professor of Department of Chemistry, Faculty of Mathematics and Natural Sciences, Andalas Univesity. His research is in chemical of Sumatran plants which is used as traditional medicine by the community

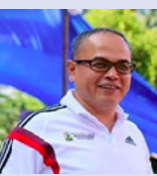

Dachriyanus got his undergraduate degrees from Andalas University in 1991 and finished his PhD from University of Western Australia in 1999. He is positioned as Professor of Pharmacy at Faculty of Pharmacy, Andalas University. His research is in chemical and biological activity studies of Sumatran Plants especially Genus Garcinia and Rhodomyrtus tomentosa.

Cite this article: Susanti M, Ibrahim S, Dachriyanus HY. Comparison between High Performance Thin Layer Chromatography and High Performance Liquid Chromatography Methods for Determination of Rubraxanthone in the Stem Bark Extract of Garcinia cowa Roxb. Pharmacog J. 2018;10(6)Suppl:s42-s47. 